\title{
A terhességet megelőzően alkalmazott hosszabb távú orális fogamzásgátlás mint a magzati 2l-es triszómia lehetséges kockázatcsökkentő tényezője idős anyai életkorban vállalt terhességben
}

\author{
Horányi Dániel dr. ${ }^{1}$ - Babay Lilla Éva dr. ${ }^{2}$ \\ Győrffy Balázs dr. ${ }^{3,5}$. Nagy Gyula Richárd dr. ${ }^{4}$ \\ ${ }^{1}$ Péterfy Sándor Utcai Kórház-Rendelőintézet és Baleseti Központ, Szülészeti és Nőgyógyászati Osztály, Budapest \\ ${ }^{2}$ Uzsoki Utcai Kórház, Szülészeti és Nőgyógyászati Osztály, Budapest \\ Semmelweis Egyetem, Általános Orvostudományi Kar, ${ }^{3}$ II. Gyermekgyógyászati Klinika, \\ ${ }^{4}$ I. Szülészeti és Nőgyógyászati Klinika, Budapest \\ ${ }^{5}$ MTA Természettudományi Kar, Enzimológiai Intézet, Budapest
}

\begin{abstract}
A Down-szindróma a leggyakrabban előforduló autoszomális kromoszóma-rendellenesség. A klasszikus értelmezés szerint a meiosis során létrejövő nondiszjunkció következménye. Előfordulása idősebb anyai életkorban gyakoribb. A genetikai rendellenesség kórélettana az intenzív kutatások ellenére sem teljesen tisztázott. Az újabb kutatások szerint egy másfajta mechanizmus állhat a 2l-es triszómia hátterében, mint amilyet eddig gondoltunk. A petefészekmozaicizmus-modell alapján a 2l-es triszómia (vagy bármely gyakori triszómia) a kromoszóma praemeioticus mitózisban bekövetkező szegregációs hibájára vezethető vissza. A meiosisba lépő örökítősejt tehát már egy eleve triszómiás petesejt lesz, melynek így a későbbiekben a szükségszerü (úgynevezett „szekunder”) nondiszjunkciója zajlik. A triszómiás petesejtek érésükben lemaradni látszanak a diszómiás (azaz normális) petesejtekhez képest. Az idő előrehaladtával a petefészekben relatíve felhalmozódnak: a triszómiás/diszómiás petesejtek aránya kedvezőtlenebb lesz előrehaladott anyai életkorban. Ha gátoljuk az ovulációt - bár az apoptózis miatt a petesejtek száma továbbra is csökkenni fog -, feltételezhető, hogy a triszómiás/diszómiás petesejtek aránya nem romlik, idősebb anyai életkorban is kedvezőbb marad. Összefoglaló közleményünkben - korábbi adataink bemutatásával és kiegészítésével - arra szeretnénk rámutatni, hogy a petefészekmozaicizmus-modell alapján idősebb anyai életkorban vállalt terhesség esetén elönyös lehet az anamnézisben szereplő hosszabb távú orális fogamzásgátlás.
\end{abstract}

Orv Hetil. 2018; 159(28): 1146-1152.

Kulcsszavak: Down-szindróma, orális fogamzásgátlás, triszómia, petefészekmozaicizmus-modell

\section{Longer oral contraception history as a possible preventive factor against fetal trisomy 21 in advanced maternal age pregnancies}

Down syndrome is the most common autosomal chromosomal abnormality. According to the classical interpretation, it is the result of meiotic nondisjunction. Its occurrence is more common in advanced maternal age. Despite intensive research, pathophysiology of this genetic disorder is not fully understood. According to recent studies, a different kind of mechanism may be found in the background of trisomy 21 than was previously considered. Based on the ovarian mosaicism model, the cause of trisomy 21 (or any common trisomy) is a segregation error of a chromosome in premeiotic mitosis. The cell entering meiosis will be an oocyte with preexisting trisomy, where its (so-called "secondary") nondisjunction is essential. Maturation of the trisomic oocytes appears to fall behind the disomic oocytes, resulting in their relative accumulation in the ovaries as time progresses. The ratio of trisomic/disomic cells becomes 
less favorable in maternal maturity. If ovulation is inhibited - although the number of oocytes will continue to decline due to apoptosis - it can be assumed that the trisomic/disomic oocyte ratio remains more favorable with the progression of age. In our summary report, presenting and updating our previous data, we would like to propose that - according to ovarian mosaicism model - long-term oral contraception in the anamnesis may be beneficial in pregnancies with advanced maternal age.

Keywords: Down syndrome, oral contraception, trisomy, ovarian mosaicism model

Horányi D, Babay LÉ, Győrffy B, Nagy GyR. [Longer oral contraception history as a possible preventive factor against fetal trisomy 21 in advanced maternal age pregnancies]. Orv Hetil. 2018; 159(28): 1146-1152.

(Beérkezett: 2018. február 18.; elfogadva: 2018. március 22.)

\section{Rövidítések}

$\mathrm{AFC}=($ antral follicle count $)$ antralis folliculusok száma; AMH $=$ anti-Müller-hormon; ATP $=$ adenozin-trifoszfát; FSH $=$ folliculusstimuláló hormon - tüszőserkentő hormon; OAC = (orális antikoncipiens) orális fogámzásgátló; OMS = (ovarian mosaicism model) petefészekmozaicizmus-modell

A Down-szindróma hátterében álló 21-es triszómia a leggyakrabban előforduló autoszomális kromoszómarendellenesség, mely szellemi leépüléssel, értelmi fogyatékossággal jár együtt. Az esetek többségében (95\%) - a klasszikus értelmezés szerint - a meiosis során létrejövô nondiszjunkció következménye, amikor a betegnek 47 kromoszómája van (ebből három 2l-es kromoszóma). Idősebb anyai életkorban előfordulása gyakoribb. Az esetek kis részében (3-4\%) transzlokáció áll a hátterében (ennek a ritkább formának az előfordulása nem függ az anyai életkortól). Nagyon ritkán (1-2\%) postmeioticus nondiszjunkció következtében kialakult mozaikformáról van szó, itt normál és 21 -es triszómiás sejtvonalak együttesen fordulnak elő [1].

Napjainkban a gyermekvállalás egyre későbbre tolódásával a 21 -es triszómia kockázata is emelkedik, hiszen elörehaladott anyai életkorban (35 éves kor után) a leggyakoribb 21-es triszómiaforma rizikója fokozott. A plusz egy kromoszóma leginkább anyai eredetú, minden 80 petesejt közül 1 petesejtnek van egy extra 21 -es kromoszómája [2].

A genetikai rendellenességek kórélettana az intenzív kutatások ellenére sem teljesen tisztázott.

\section{A klasszikus eredetmodell: meioticus nondiszjunkció}

Jelenleg a legismertebb elmélet szerint a 21 -es triszómia kialakulásakor meioticus nondiszjunkció történik egy egyébként egészséges, diszómiás petesejtben $[3,4]$. A meioticus nondiszjunkció a homológ kromoszómapárok vagy a testvérkromatidák szétválásának zavara a meiosis során. A nondiszjunkció megvalósulhat: (1) a meiosis I. során, amikor a homológ kromoszómapárok nem válnak szét, (2) a meiosis II. során, amikor a testvérkromatidák szétválása hiúsul meg [5]. Számos hipotézis született arra vonatkozólag, hogy ez milyen módon állhat összefüggésben az anyai életkorral mint ismert rizikótényezővel.

Az egyik ilyen hipotézis a ,production line”, amely szerint a várandósság előrehaladásával a termelődő petesejtek szerkezeti eltérésük miatt egyre fogékonyabbá válnak a nondiszjunkcióra. A feltételezés szerint a petesejtek beérésének sorrendjét a méhen belüli kialakulási sorrend határozza meg, ezért fordulhat elő nagyobb valószínúséggel nondiszjunkció (és ezáltal 21-es triszómia) idősebb anyai életkorban [6]. Az „öregedő petesejtek (ageing oocyte)" hipotézis a 2l-es triszómia okát a petesejtérés zavarában keresi, a meioticus osztódás leállásának időtartama során [7]. A hosszú meioticus profázis I. alatt a kromoszómák károsodását külső és belső tényezők egyaránt okozhatják. A káros sugárzások, a nehézfémek ionjai a petesejteket intracelluláris oxidatív folyamatok révén károsíthatják; a petesejtek sugárérzékenysége ebben a stádiumban igen magas, és a kor előrehaladásával tovább növekszik [8].

A mikrocirkulációs modell alapján a nondiszjunkció kaszkádok sorozata [9]. Kialakulásának folyamatában a hormonális zavar, a tüsző körüli szövet szuboptimális erezettsége, a csökkent véráramlás, a tüsző́n belüli széndioxid és laktát emelkedése, a petesejtben a csökkenő $\mathrm{pH}$, a kisebb mitotikus orsó és az orsó elmozdulásának összessége okozhatja a kromoszóma károsodását. Elképzelés született arról is, hogy a mitokondriális DNS mutácioja következtében az ATP-szint lecsökken, és a szabad gyökök koncentrációja megemelkedik, kialakítva a kromoszómaszegregáció zavarát s így a kromoszóma nondiszjunkcióját [10].

Általánosan elfogadott tény, hogy az idősebb anyai életkor fokozottabb kockázatot jelent a Down-szindróma kialakulására; ezt minden teória leírja. Az viszont, hogy a meioticus nondiszjunkció mint hiba hogyan lesz egyre gyakoribb az anyai életkor elórehaladtával, nehezen magyarázható, inkább csak elméleti fejtegetés marad. 


\section{A petefészekmozaicizmus-modell}

Újabb kutatások szerint egy másfajta mechanizmus állhat a 21 -es triszómia hátterében. Mielőtt ennek ismertetésére rátérnénk, nézzük át, hogyan zajlik a sejtosztódás a petesejtekben: a terhesség 8 . hetében egy leánymagzat petefészkében körülbelül 600000 primitív csírasejt van, számuk a 20. terhességi héten éri el a maximumot, a 40 milliót. A 20. héttől beinduló follicularis atresia miatt a születés idôpontjára ezen sejtek száma már csak 3 millió lesz, a nemi érés idejére pedig mindösszesen kb. 400000 marad. Ebből a fogamzóképes kor alatt kb. 400-480 csírasejt válik megtermékenyíthető petesejtté, a többi programozott sejthalál áldozata lesz [11]. A meioticus sejtosztódás tehát a várandósság 9. hetében kezdődik (profázis I.), majd leáll egészen a pubertáskorig, amikor az első meioticus sejtoszlás (metafázis I., anafázis I., telofázis I.) éppen az ovuláció előtt fejeződik be. A profázis II. és a metafázis II. után megtörténik az ovuláció, majd ismét nyugvó állapot következik be, a második meioticus sejtosztódás (anafázis II. és telofázis II.) már csak a megtermékenyítés után komplettálódik. Összességében tehát egy normál meioticus sejtoszlási folyamat 12-50 évig is eltarthat [12].

Egy 2008-ban megjelent cikkben Hultén és mtsai a Down-szindróma kialakulása kapcsán paradigmaváltást vizionáltak: véleményük szerint a kórkép háttere az ovarialis mozaicizmusban keresendő [13]. A modell alapköve - és egyben fó eltérése a klasszikus értelmezéssel szemben -, hogy a hiba a praemeioticus mitózisban történik meg (amikor a primitív csírasejtek létrejönnek), így már eleve egy 21 -es triszómiás petesejt „szükségszerü”, úgynevezett szekunder nondiszjunkciója történik a meiosis során [14].

A petefészekmozaicizmus-modell (ovarian mosaicism model - OMS) alapján a 21 -es triszómia tehát egy praemeioticus mitózisban bekövetkező szegregációs hibára vezethetô vissza, s nem egy későbbi időpontban, idős anyai életkorban jelentkező probléma következménye. $\mathrm{Az}$ elképzelést alátámasztja az a megfigyelés is, amikor 14-22 hetes, fenotípusosan normális leánymagzatok petefészkének vizsgálatakor minden esetben petefészekmozaicizmust találtak [13]. A diszómiás sejtek mellett átlagosan a sejtek $0,54 \%$-a 21 -es triszómiás volt $(0,20$ $0,88 \%$ a teljes sejtpopulációban, tehát a praemeioticus és a mesenchymalis sejtekben is). Eredményeik alapján a $2 \mathrm{l}$-es triszómiás petesejtek már magzati korban, a meiosist megelőző mitózis állapotában is jelen vannak, és nem később alakulnak ki az idősödő nő petefészkében.

Fontos megfigyelés, hogy a 2l-es triszómiás sejtek, összehasonlítva normális (diszómiás) társaikkal, érésükben lemaradni látszanak [15]. A diszómiás petesejtek gyorsabban érnek meg, számuk ezért gyorsabban csökken, mint triszómiás társaiké. Ennek következtében arányaiban több triszómiás petesejt maradhat az előrehaladott anyai életkorra [16]. Ez magyarázza az életkor előrehaladtával kapcsolatos kockázatemelkedést a triszómiás terhesség kialakulására.

Hultén és mtsai feltételezésének nyomán tehát a 21 -es triszómiás petesejtek a normális petefészekszövetben már eleve jelen vannak egy kromoszomális mozaicizmus részeként [16], ami nem eseti eltérés, hanem fontos biológiai jelenség, a genetikai sokszínúség, a prenatális fejlődés része, s szerepe lehet a posztnatális élet folyamán megfigyelt betegségek kialakulásában vagy akár az öregedésben [17].

\section{Az orális fogamzásgátlók lehetséges kedvező hatása a triszómiás sejtek arányára}

A petefészekmozaicizmus-modell alapján tehát az életkor elörehaladtával a triszómiás/diszómiás petesejtek aránya fokozatosan emelkedik (miközben az összpetesejtszám folyamatosan csökken) [16]. Számarányuk és gyorsabb érésük miatt fiatal anyai életkorban nagy valószínúséggel a diszómiás petesejtek jutnak el az ovulációig, idősebb anyai életkorban viszont fokozódik annak a veszélye, hogy egy triszómiás petesejt is kiválasztódjon, megérjen és ovuláljon. Ha a számos ovuláció során hamarabb „fogynak el” a diszómiás petesejtek, és minél több ovuláció történik, annál nagyobb valószínúséggel fog egy triszómiás petesejt is ovulálni, kézenfekvőnek látszott górcső alá venni azokat a hatásokat, amelyek gátolják az ovulációt. Vajon ezeknek a tényezőknek lehet-e szerepük a triszómiák rizikócsökkentésében?

A nő élete során bekövetkező ovulációinak számát sok tényező befolyásolhatja. Ilyen például az első menses időpontja, a menstruációs ciklusok hossza, a terhességek és a szoptatás időszaka miatt kimaradt vagy az orális hormonális fogamzásgátlók (OAC - orális antikoncipiens) szedésének kapcsán kimaradt ovulációk száma.

Egy 2013-ban megjelent tanulmányunkban 5222 magzatvíz-mintavétel adatait áttanulmányozva 119 strukturális vagy számbeli kromoszómaeltérést találtunk. Ezekből az esetekből kiválasztottuk azokat, amelyekben idős anyai életkorban történt a vizsgálat, és 21 -es, 18-as vagy 13-as triszómia igazolódott. Az így kapott 37 esetben megvizsgáltuk az ovulációk számát befolyásoló tényezőket, és összehasonlítottuk az adatokat egy olyan kontrollcsoportéival, amelyben szintén idős anyai életkorban történt magzatvíz-mintavétel egészséges terhességet igazolt. Eredményeink nem mutattak szignifikáns különbséget az anyai életkor, az első menstruáció, a menstruációs ciklus hosszúsága, a korábbi vetélések és terhességek száma között. Szignifikáns különbség mutatkozott viszont abban a tekintetben, hogy a terhességet megelőző időszakban összességében (akár kisebbnagyobb megszakításokkal is) mennyi ideig szedett valaki hormonális fogamzásgátló tablettát (triszómiás terhességben 3,4 év versus 6,0 év a kontrollcsoportban, $\mathrm{p}<0,0014)$. Az elemzésból tehát arra derült fény, hogy az anamnézisben szereplő hosszabb távú OAC-használat előnyös idős anyai életkorban vállalt terhességek esetén, 
mert a gyakori triszómiák rizikójának csökkenésével társult [18].

$\mathrm{Az}$ OAC hatásmechanizmusának egyik pillére az ovuláció gátlása. Az ovulációgátló hatás következtében persze hosszú távon nem marad több petesejt a petefészekben, hiszen az apoptózis miatt a petesejtek száma folyamatosan csökken. Joggal feltételezhetjük azonban, hogy az apoptózis egyformán hat mind a triszómiás, mind a diszómiás petesejtekre, így az ovuláció gátlásakor a triszómiás/diszómiás petesejtek aránya nem változik [19, 20]. Mivel az ovulációk fokozott számával a triszómiás/diszómiás petesejt arány romlik, az ovulációk gátlásával kedvezőbb arányszám „konzerválható”.

Ha idős anyai életkorban vállal egy nő terhességet, az előzményben szereplő hosszabb távú fogamzásgátlótabletta-szedés (hosszabb távú ovulációgátlás) a gyakori triszómiák előfordulását csökkentheti, hiszen a „felesleges” ovulációk gátlásával kedvezőbb triszómiás/diszómiás petesejt arányt eredményezhet.

\section{Befolyásolja a dobányzás a korábban igazolt adatokat?}

A különböző triszómiák hátterének vizsgálatakor a környezeti tényezők között felmerült a perikoncepcionális dohányzás [21] és a dohányrágás is [22, 23].

Vizsgálatainkat folytatva és adatainkat kibővítve, egy újabb tanulmányban 2332 magzatvíz-mintavétel adatait tanulmányoztuk át: itt 75 esetben találtunk strukturális vagy számbeli eltérést. Ismételten azokat az eseteket válogattuk ki, amelyekben idős anyai életkorban történt a vizsgálat, mely 21 -es, 18-as vagy 13-as triszómiát igazolt. A vizsgálat során 35 esetben állt rendelkezésünkre az összes szükséges kórtörténeti adat, melyek pontosságát - ennél a tanulmánynál - telefonos interjúk segítségével is ellenőriztük. A menstruáció kezdetéből, a menstruációs ciklus hosszából, a terhesség előtti utolsó menses időpontjából, a korábbi terhességekből és vetélésekből ismét megbecsültük az ovulációk számát. Adatokat gyűjtöttünk az OAC-használók dohányzási szokásairól is, ami szintén feltételezett rizikófaktora a Down-szindróma-kockázat emelkedésének [21]. Kíváncsiak voltunk arra, hogy a korábbi tanulmányban nem vizsgált dohányzási szokások befolyásolják-e eredményeinket. Szignifikáns különbség ebben a tanulmányban sem mutatkozott az anyai életkor, az átlagos menstruációs ciklus, a terhességek száma, a spontán vetélések és a terhességmegszakítások tekintetében a beteg- és a kontrollcsoport között. Az OAC-használat azonban itt is szignifikáns különbséget mutatott: előrehaladott anyai életkorban a triszómiás várandósságok esetében az anamnézisben szerepló OAC-szedés időtartama rövidebb volt, mint egészséges terhességek esetén $(3,2$ versus 6,0 év, $p<0,001)$. A perikoncepcionális dohányzás tekintetében viszont nem volt szignifikáns különbség a beteg- és a kontrollcsoport között (NS, p = 0,698) [19, 20].
A dohányzás ugyanakkor károsítja a magzat fejlődését. A nikotin az érösszehúzódást okozó hatása miatt csökkenti az uteroplacentaris keringést. A dohányzó nők cigarettafogyasztásával arányos a magzati sorvadás előfordulása és súlyossága is [24].

\section{A petefészken végzett mütétek és az idősebb korban előforduló triszómiák kockázata közötti kapcsolat}

A petefeszekben jelentkező ciszták, képletek mútéti eltávolítása során a petefészek állománya sérül. A petefészek térfogata csökken, ez egyértelmúen befolyásolja a petesejtrezerv mennyiségét is, a petefészek múködését és a petesejtek számát. Reproduktív korban alapvető törekvés a mútét során a petefészek legnagyobb kímélete. Jóindulatú betegségek (endometrioma, funkcionális tömlők, dermoid ciszta stb.) esetében ez egyszerúen kivitelezhető, a tömlő eltávolításával a petefészek-állomány legkisebb sérülésével járó mútéttel. Fertilis korban előforduló rosszindulatú petefészek-daganat esetén azonban - sokszor a megfelelő radikalitás érdekében - nem elegendő a petefészekből a kimetszés, hanem az érintett oldali petefészek eltávolítása javasolt. Ezek a tényezők egyértelmúen a petefészekrezerv csökkenéséhez vezetnek. Ding és $m$ tsai [25] a jóindulatú betegségek eseteiben operált betegeknél a petefészekrezerv mérésére az AMH-t (antiMüller-hormon), az FSH-t (folliculusstimuláló hormon) és a tüszőszámot (AFC - antral follicle count), a petefészek-térfogatot és az ovariumstroma pulzatilis indexét használták fel. Eredményeik az FSH-szint szignifikáns emelkedése mellett, az AMH és az AFC szignifikáns csökkenését mutatták kétoldali endometriomaeltávolításon átesett betegeknél, természetesen a petefészek-térfogat szignifikáns csökkenésével az első hónapban. Érdekesség, hogy eredményeiket kontrollálva 6-12 hónappal a mútét után, nem volt mérhető különbség a petefészekrezerv markerei között az alapértékekhez képest [25]. Salihoğlu és mtsai normális petefészekciszták és az endometriomák eltávolítása során vizsgálták a mútét előtti és utáni állapotot. A preoperatívan mért AMH- és AFCértékek egyaránt alacsonyak voltak, a ciszta szövettani típusától függetlenül [26]. Az ovariumrezerv megítélésében a folliculusszám (tüszősúrüség) megbecslésére az AMH alkalmas marker [27]. Fabbri és mtsai a rosszindulatú daganatos megbetegedésben szenvedô reproduktív korú nőknél vizsgálták az AMH szerepét. Véleményük szerint az AMH alkalmas a petefészekrezerv megítélésére, pozitív összefüggést állítottak fel az AMH és primordialis tüszősưrüség között [28].

A petefészekciszta operációja mindenképpen a petefészek-állomány csökkenésével jár együtt. Mivel pontosan nem lehet meghatározni, hogy a petefészek melyik részében helyezkednek el a - már korábban elmondottak alapján eleve - triszómiás vagy diszómiás petesejtek, ezért logikusan a triszómiás/diszómiás arány lineáris 
csökkenésével kell számolnunk petefészekmútétek esetén. Ez azt jelenti, hogy a mútét során eltávolított petefészek-állomány mennyisége bár a petesejtek számát csökkenti, de a triszómiás/diszómiás arányt nem változtatja meg; a mû́tét maga véleményünk szerint nem befolyásolja a triszómia rizikóját. Freeman és mtsai korábban ennek ellenkezőjét írták le: a petefészkek méretének sebészi csökkentése után egy későbbi terhességben a triszómiák előfordulási gyakoriságának emelkedését találták [29].

Kíváncsiak voltunk, hogy ezzel kapcsolatosan milyen saját adataink vannak.

A 2017-ben közölt tanulmányunk során, 2 év (2013. szeptember 1. - 2015. szeptember 1.) 12776 genetikai tanácsadásának adatait tekintettük át: 2332 esetben történt genetikai amniocentesis, amely 75 esetben igazolt kromoszóma-rendellenességet. Ezek közül 45 esetben idős anyai életkorban igazolt a vizsgálat 21 -es, 18-as vagy 13 -as triszómiát, de csak 35 esetben fértünk hozzá az összes szükséges kórtörténeti adathoz. A betegcsoportot képező 35 esetből 26 esetben állt rendelkezésünkre az adnexumokon végzett mútétekkel kapcsolatban adat. A tanulmány 100 fós kontrollcsoportjából 59 esetben volt információnk arról, hogy történt-e az anamnézisben petefészekmútét.

Számításaink alapján a kontroll- és vizsgált csoport között nem volt statisztikailag szignifikáns különbség sem az átlag anyai életkorban, sem a menarche idópontjában, sem a ciklusok hosszában, sem a terhességek számában, a spontán vagy múvi vetélések viszonylatában sem. A kontrollcsoportban $2(3,4 \%)$, a betegcsoportban 1 $(3,8 \%)$ petefészekmútét történt, így szignifikáns különbség a petefészekmútétek számában sem mutatkozott.

$\mathrm{Az}$ alacsony esetszám miatt korlátozott értékűek a saját adatainkból levonható következtetések, ezért kitekintést végeztünk a nemzetközi irodalomban is.

A PubMed adatbázisában egy cikket találtunk az alábbi keresőszavakkal: oocyte pool; ovarian reserve; ovarian surgery; trisomic pregnancy; trisomy. Ha az „ovarian reserve, ovarian surgery, trisomies" keresést alkalmaztuk, ez 4 cikket eredményezett; az „ovarian surgery; trisomies” keresést alkalmazva 25 cikk került listázásra, ezek közül kettő - Freeman és Honorato cikke [29, 30] - foglalkozik teljes terjedelmében a petefészken végzett mútétek és a triszómiák kapcsolatával.

Míg Freeman és mtsai [29] összefüggést igazoltak a triszómiák előfordulási gyakoriságának emelkedése és a petesejtrezerv csökkenése között, addig a másik kutatócsoport ezt nem igazolta. Honorato és mtsai [30] szerint nincs releváns összefüggés a petefészken végzett mútetek és a triszómiák előfordulása között. Tanulmányukban 1723 esetet vetettek össze 6850 kontrollal: a triszómiás terhességet viselő nők esetében 46/1723 (2,7\%), a kontrollcsoportban $172 / 6850(2,5 \%)$ esetben volt petefészekmútét az előzményben; ez azt jelentette, hogy nem volt szignifikáns különbség a két csoport között. Honorato és mtsai tehát hasonló előfordulási arányban írták le a petefészekmútétek gyakoriságát, mint amit mi is megfigyeltünk. Tanulmányuk korlátjaként jelölték meg, hogy nem gyújtöttek adatokat a hosszú távú orális hormonális fogamzásgátlással kapcsolatosan.

Freeman és Honorato tanulmányai között lényeges a publikációk között eltelt 15 év. Míg Freeman 2000-ben elsősorban a jelentősebb mennyiségú ovariumrezerv hiányát emeli ki (például az egyik oldali petefészek eltávolítása), addig feltételezhetjük, hogy Honorato 2015-ös publikációja már olyan eseteket tartalmaz, amelyekben a fejlődő mútéttechnikának megfelelően már inkább a petefészekrezerv megkímélése lehetett a cél, így vélhetően a vizsgált esetekben kisebb volt az eltávolított petefészekrészlet nagysága, mint a 15 évvel korábban publikált tanulmányban. Pontos adatok az eltávolított petefészekrészletek nagyságáról nem ismertek.

A fenti tanulmányokat és saját hipotézisünket figyelembe véve feltételezhető, hogy a petefészken napjainkban végzett mútétek érdemben nem befolyásolják egy késóbb vállalt terhesség esetén a triszómiák előfordulási kockázatát. A petefészektérfogat-csökkenés aránya kivetíthető az adott térfogatban lévő triszómiás/diszómiás petesejtek arányára is. Ha ezt adott időpillanatban konstans értéknek vesszük, akkor a kisebb vagy nagyobb petefészekben ennek az aránynak változatlannak kell maradnia, ami nem eredményezhet kockázatváltozást. Ha viszont olyan jelentős mennyiségú petefészekszövet kerül eltávolításra, amely jelentős mértékben közelebb hozza a menopauza idejét, a hamarabb megérô diszómiás és a később érô triszómiás sejtek miatt a legutolsó ovulációk már inkább a triszómiás petesejtek közül kerülhetnek ki, s feltehetóen ez az a jelenség, amelyet Freeman is megfigyelt.

\section{Következtetés}

A petefészekmozaicizmus-modell alapján a 21 -es triszómia hátterében egy praemeioticus mitózisban bekövetkező szegregációs hibát feltételezhetünk. Ezt követően egy szükségszerú (másodlagos) meioticus nondiszjunkció következtében jönnek létre a 2l-es triszómiás petesejtek, melyek relatív felhalmozódása fokozhatja a Down-szindróma gyakoriságát előrehaladott anyai életkorban [31].

Az OAC-használattal kapcsolatosan gyújtött adatok feldolgozása alapján eredményeink azt mutatják, hogy a terhesség elótti időszakban hosszabb távon használt orális fogamzásgátlók csökkentik a Down-szindróma rizikóját idős anyai életkorban vállalt terhességek esetén. A dohányzással kapcsolatos adatok ezen eredményeket érdemben nem befolyásolták $[19,20]$. Véleményünk szerint a petefészken végzett mútétek sem befolyásolják érdemben a triszómiák előfordulását előrehaladott anyai életkorban.

A hormonális fogamzásgátlás ismert előnyös és hátrányos hatásai széles körúek [32], de eredményeink alapján felvethető, hogy az előnyös hatások kiegészülhetnek a 
triszómiák kockázatcsökkentő hatásával is. Jelentőségét emelheti, hogy a fiatalok megbízhatóbb módszernek tartják, mint az óvszerrel való védekezést [33]. Jelenleg megbízható hormonális fogamzásgátló módszer a férfiak számára egyébként sem áll rendelkezésre [34], ezért a nők számára lehetséges orális hormonális fogamzásgátlásnak a családtervezésben betöltött szerepe teljesedhet ki ezzel a hatással. A Down-szindróma megelőzésére egy kockázatcsökkentő módszer megtalálása azért is nagyon fontos, mert a gyermekvállalás egyre későbbi anyai életkorra tolódik. Eredményeink nagyobb esetszámot magában foglaló független bizonyítást igényelnek, de elörevetítik annak lehetőségét, hogy előrehaladott anyai életkorban, az anamnézisben szereplő hosszabb távú orális hormonális fogamzásgátlás előnyös lehet a triszómiák rizikójának csökkentésében.

Anyagi támogatás: A közlemény megírása anyagi támogatásban nem részesült.

Szerzői munkamegosztás: A kézirat elkészítésében a szerzők azonos mértékben vettek részt. A cikk végleges változatát valamennyi szerző elolvasta és jóváhagyta.

Érdekeltségek: A szerző́knek nincsenek érdekeltségeik.

\section{Irodalom}

[1] Papp Z, Hajdú J. Congenital anomalies, intrauterine (connatal) infections. In: Papp Z. (ed.) Obstetrics and gynecology. [Congenitalis anomáliák, intrauterin (connatalis) infectiók. In: Papp Z. (szerk.) A szülészet-nőgyógyászat tankönyve.] Semmelweis Kiadó, Budapest, 2009; pp. 409-445. [Hungarian]

[2] Iwarsson E, Kvist U, Hultén MA. Disomy 21 in spermatozoa and the paternal origin of trisomy 21 Down syndrome. $\mathrm{Mol} \mathrm{Cy}$ togenet. $2015 ; 8: 67$.

[3] Ghosh S, Feingold E, Dey SK. Etiology of Down syndrome: Evidence for consistent association among altered meiotic recombination, nondisjunction and maternal age across populations. Am J Med Genet A 2009; 149: 1415-1420.

[4] Allen EG, Freeman SB, Druschel C, et al. Maternal age and risk for trisomy 21 assessed by the origin of chromosome nondisjunction: a report from the Atlanta and National Down Syndrome Projects. Hum Genet. 2009; 125: 41-52.

[5] Bacino CA, Lee B. Cytogenetics. In: Kliegman R, Stanton BF, St. Geme JW, et al. (eds.) Nelson Textbook of Pediatrics, 19th Edition. Elsevier/Saunders, Philadelphia, PA, 2011; pp. 394413.

[6] Henderson SA, Edwards RG. Chiasma frequency and maternal age in mammals. Nature 1968; 218: 22-28.

[7] Eichenlaub-Ritter U. Genetics of oocyte ageing. Maturitas 1998; 30: 143-169

[8] Tease C, Fisher G. The influence of maternal age on radiationinduced chromosome aberrations in mouse oocytes. Mutat Res. 1991; 262: 57-62.

[9] Gaulden ME. Maternal age effect: The enigma of Down syndrome and other trisomic conditions. Mutat Res. 1992; 296: 69-88.

[10] Arbuzova S. Why it is necessary to study the role of mitochondrial genome in trisomy 21 pathogenesis? Downs Syndr Res Pract. 1998; 5: 126-130.
[11] Borsos A, Urbancsek J. Physiological function and dysfunction of female genital organs. In: Papp Z. (ed.) Obstetrics and gynecology. [A női nemi szervek élettani múködése és funkcionális zavarai. In: Papp Z. (szerk.) A szülészet-nőgyógyászat tankönyve.] Semmelweis Kiadó, Budapest, 2009; pp. 75-105. [Hungarian]

[12] Papp Z, Tóth Z. Conception and phyisiologic pregnancy. In: Papp Z. (ed.) Obstetrics and gynecology. [Fogamzás és élettani terhesség. In: Papp Z. (szerk.) A szülészet-nőgyógyászat tankönyve.] Semmelweis Kiadó, Budapest, 2009; pp. 127-170. [Hungarian]

[13] Hultén MA, Patel SD, Tankimanova M, et al. On the origin of trisomy 21 Down syndrome. Mol Cytogenet. 2008; $1: 21$.

[14] Cooper KW. A new theory of secondary non-disjuntion in female Drosophila melanogaster. Proc Natl Acad Sci USA 1948; 34: 179-187.

[15] Barlow AL, Tease C, Hultén MA. Meiotic chromosome pairing in fetal oocytes of trisomy 21 human females. Cytogenet Genome Res. 2002; 96: 45-51.

[16] Hultén MA, Patel S, Jonasson J. On the origin of the maternal age effect in trisomy 21 Down syndrome: the oocyte mosaicism selection model. Reproduction 2010; 139: 1-9.

[17] Iourov IY, Vorsanova SG, Yurov YB. Chromosomal mosaicism goes global. Mol Cytogenet. 2008; 1: 26.

[18] Nagy GR, Győrffy B, Nagy B, et al. Lower risk for Down syndrome associated with longer oral contraceptive use: a case-control study of women of advanced maternal age presenting for prenatal diagnosis. Contraception 2013; 87: 455-458.

[19] Horányi D, Babay LÉ, Rigó J Jr, et al. Effect of extended oral contraception use on the prevalence of fetal trisomy 21 in women aged at least 35 years. Int J Gynaecol Obstet. 2017; 138: 261-266.

[20] Horányi D, Babay LÉ, Rigó J Jr, et al. Erratum to "Effect of extended oral contraception use on the prevalence of fetal trisomy 21 in women aged at least 35 years" [Int J Gynecol Obstet. 2017; 138: 261-266]. Int J Gynaecol Obstet. 2018; 140: 258.

[21] Yang Q, Sherman SL, Hassold TJ, et al. Risk factors for trisomy 21: maternal cigarette smoking and oral contraceptive use in a population-based case-control study. Genet Med. 1999; 1: 8088.

[22] Ghosh S, Hong CS, Feingold E, et al. Epidemiology of Down syndrome: new insight into the multidimensional interactions among genetic and environmental risk factors in the oocyte. Am J Epidemiol. 2001; 174: 1009-1016.

[23] Ray A, Hong CS, Feingold E, et al. Maternal telomere length and risk of Down syndrome: Epidemiological impact of smokeless chewing tobacco and oral contraceptive on segregation of chromosome 21. Public Health Genomics 2016; 19: 11-18.

[24] Papp Z. Textbook of Obstetrics and Gynecology. Fifth edition. [A szülészet-nőgyógyászat tankönyve. Ötödik kiadás.) Semmelweis Kiadó, Budapest, 2017; pp. 165-214. [Hungarian]

[25] Ding Y, Yuan Y, Ding J, et al. Comprehensive assessment of the impact of laparoscopic ovarian cystectomy on ovarian reserve. J Minim Invasive Gynecol. 2015; 22: 1252-1259.

[26] Salihoğlu KN, Dilbaz B, Cirık DA, et al. Short-term impact of laparoscopic cystectomy on ovarian reserve tests in bilateral and unilateral endometriotic and nonendometriotic cysts. J Minim Invasive Gynecol. 2016; 23: 719-725.

[27] Garavaglia E, Sala C, Taccagni G, et al. Fertility preservation in endometriosis patients: anti-Müllerian hormone is a reliable marker of the ovarian follicle density. Front Surg. 2017; 4: 40.

[28] Fabbri R, Macciocca M, Melotti C, et al. Anti-Müllerian hormone as an ovarian reserve marker in young cancer women who undergo ovarian tissue cryopreservation. Future Oncol. 2014; 10: 1343-1351.

[29] Freeman SB, Yang Q, Allran K, et al. Women with a reduced ovarian complement may have an increased risk for a child with Down syndrome. Am J Hum Genet. 2000; 66: 1680-1683. 
[30] Honorato TC, Henningsen AA, Haadsma ML, et al. Follicle pool, ovarian surgery and the risk for a subsequent trisomic pregnancy. Hum Reprod. 2015; 30: 717-722.

[31] Hultén MA, Öijerstedt L, Iwarsson E, et al. Maternal germinal trisomy 21 in Down syndrome. J Clin Med. 2014; 3: 167-175.

[32] Dayal M, Barnhart K. Noncontraceptive benefits and therapeutic uses of the oral contraceptive pill. Semin Reprod Med. 2001; 19: 295-303

[33] Devosa I, Kozinszky Z, Vanya M, et al. Knowledge of university students in Szeged, Hungary about reliable contraceptive methods and sexually transmitted diseases. [Szegedi egyetemi hall- gatók ismeretei a megbízható fogamzásgátlásról és a szexuális úton terjedő nemi betegségekről.] Orv Hetil. 2016; 157: 539546. [Hungarian]

[34] Pásztor N, Hegyi BE, Badó A, et al. Male hormonal contraception: past, present, future. [Férfi hormonális fogamzásgátlás: múlt, jelen, jövő.] Orv Hetil. 2017; 46: 1819-1830. [Hungarian]

(Horányi Dániel dr., Budapest, Péterfy S. u. 8-20., 1076 e-mail: horanyidani@gmail.com)

\section{MEG HÍ Vó}

\section{ROMHÁNYI ORVOSTALÁLKOZÓ \\ Lelkigyakorlat (manreza) orvosoknak \\ Helyszín: SZÁR - Római katolikus templom Időpont: 2018. szeptember 1.}

\section{Fontos információk!}

Részvételi szándékát szíveskedjék augusztus 20 -ig jelezni

Koltayné Bartha Magdánál a 06-70/350-2062 telefonszámon naponta 14-16 óra között, vagy a baratikor.saar@gmail.com e-mail címen.

Az Orvostalálkozók eddig döntően a résztvevők áldozatos adományaiból valósultak meg.

Kérjük, hogy amennyiben lehetősége van rá, ebben az évben is támogassa rendezvényünket a Szár Község Német Kisebbségi Oktatásáért és Kultúrájáért Egyesület (UniCredit Bank 10918001-00000036-60180000) részére átutalt vagy a helyszínen kapható csekken befizetett összeggel, „Romhányi orvostalálkozó” megjegyzéssel.

\section{Program:}

\section{9:00 Szentmise}

10:00 Üdvözlések Moharos Péter, polgármester

Prof. Dr. Kellermayer Miklós: Az Igazság, amiröl József Attila ír az Isten címü versében

10:30 Bíró László tábori püspök: A szeretet boldogsága (Gondolatok a családról az Amoris Laetitia pápai buzdítás alapján

11:00 Pandula Attila dr:: Dr. boldog Batthyány-Strattmann László rendjelei és kitüntetései

11:30 Rieger Tibor szobrászmüvész: A müvészet szellemi alapja koronázó palástunktól napjainkig

14:00 Horváth J. Attila dr.: Fájdalom és szenvedés

14:30 Prof. dr. Mangel László: Az onkológia fejlődése, szakmai és lélektani szempontok alapján. Elvárások és lehetőségek, sikerek és kudarcok

15:00 Prof. dr. Emődy Levente: Romhányi György klinikopatológiai szemléletének példája az utódgenerációk számára: hivatástudat, felkészültség, perifériás látás, kreatív gondolkodás, etikai tartás

15:30 Tornóczki Tamás dr.: Localizált amyloid. Valóban annyira egyszerü?

Moderátor: Prof. dr. Szelényi Zoltán 